\title{
The Role of Higher Education in Enhancing Social Entrepreneurship
}

Abstract: Social entrepreneurship and higher education seem to form closer relationships. This paper concerns with the role of higher education in enhancing social entrepreneurship, as it is implemented in the context of Dorset, UK and Avalon, Canada. By utilising the theoretical dimensions of entrepreneurial orientation the paper develops a framework of interpretation for its empirical context. In summarising its findings, it argues that the role higher education can play for social entrepreneurship in both cases is highly regarded however there are a number of hurdles that will need to be overcome.

Keywords: Higher Education; Entrepreneurial Orientation; Social Entrepreneurship; Bournemouth University, Dorset, UK; Memorial University of Newfoundland, Avalon, Canada;

\section{Introduction}

It has been almost a century since Joseph Schumpeter identified the principles of entrepreneurship as qualities of individual willingness that go beyond everyday routines, which should support in overcoming inner-personal resistance as well as resistance of the social environment (Ebner, 2003). Since then entrepreneurship has gone a long way and it is widely accepted that entrepreneurs today increasingly need to take the initiative in designing a new approach for their business. This approach concerns everyday acts of work that contribute to the betterment of people's life affected by the business's action (Kuratko and Hodgetts, 2007). The time for a type of entrepreneurship that attributes social aspects has arrived and it is called social entrepreneurship.

Social entrepreneurship is not a newly defined concept simply because social entrepreneurs have been around for a long time (Okpara and Halkias, 2011). There is an incremental acknowledgement of the importance of social entrepreneurship in and out of the business world nowadays. Beginning with the USA, in 1993 Harvard Business School launched the "Social Enterprise Initiative", one of the milestones of this time (Defourny and Nyssens, 2006). Since then other significant foundations have set up training programmes for social enterprises and social entrepreneurs. However, in the United States social enterprise remains a very broad and ambiguous concept that refers principally to market-orientated economic activities serving a social goal (ibid). In Europe, the concept first appeared in the early 1990s associated with the community and voluntary sectors, following a stimulus that began in Italy linked to the cooperative political movement. In 2002 there was a sudden reengineering of the debate about social enterprise in the United Kingdom. The Blair government created the "Social Enterprise Coalition" and launched the "Social Enterprise Unit", a governmental agency in order to improve the knowledge on social enterprises and through this to promote social entrepreneurship at the national level (Social Enterprise Coalition, 2003; Defourny and Nyssens, 2006).

The purpose of this paper is then twofold: firstly to identify the scope for development of social entrepreneurship with regard to higher education and how this could be enhanced by particular actions of universities today; and secondly to test empirically the theoretical implications of this statement through the findings of a initial research conducted at Bournemouth University in Dorset, UK and Memorial University of Newfoundland in Avalon, Canada. In the light of this, the paper introduces a framework whose utilisation 
offers opportunities for some positive outcomes to arise whereas blended with some not applicable ones.

\section{On social entrepreneurship and its attributes}

Sandler (2010) argues that social entrepreneurship is not a new phenomenon as such but it has become very significant today, as leveraging entrepreneurial principles are used in order to solve social issues and make a difference. In this respect, definitions of social entrepreneurship could be almost exclusively based upon the context it is used for. As Light (2008: 1) contends:

'Despite enormous enthusiasm for social entrepreneurship among a new generation of change makers, the field of social entrepreneurship is not yet a field per se. It does not have paths to tenure for its young professors, a growing inventory of quantitative data for its researchers, or a guaranteed source of private or government funding for its institutions. Its elder scholars are anything but elderly, or at least they or we think we are not, and its younger scholars have to balance their interest in social entrepreneurship against work in more respected fields.'

In the UK context social enterprises compete in the market place like any other business, no matter their business skills and knowledge to pursue social issues and achieve social goals. For example, the Trees Group is one of the largest social enterprises in the East Midlands with a $£ 8$ million turnover and more than 120 staff that exist to support its subsidiary companies in the areas of training, regeneration, education, employment and sustainability (Social Enterprise Coalition, 2003; The Trees Group, 2008). According to Harding and Cowing (2004:5) social entrepreneurs are 'one species within the genus entrepreneur. They are entrepreneurs with a social mission'. In the light of this, social enterprises are 'orthodox' businesses with social objectives, 'whose surpluses are principally re-invested for that purpose in the business or in the community, rather than being driven by the need to maximise profit for shareholders and owners' (Harding and Cowing, 2004; The Observer, 20.11.2005). This means that the degree of giving back to the community indicates the level of success for the social enterprise. From a different angle Drayton (2006: 89) argues that social entrepreneurs need and deserve loyalty. This is because 'their work is not a job; it is their life'.

Entrepreneurship, and therefore its social aspect involve three principal aspects:

- A vision;

- Someone with leadership skills who can make the vision doable; and

- Willingness to build something that will develop and endure (Thompson et al, 2000).

To this extent, what is asked for is the way to provide an idea and the ensuing actions that can bring about desirable outcomes. Sykes (1999; cited by Thompson et al, 2000) defines the following three contributions to the growth of an organisation that can perhaps apply to the case of a social enterprise:

1. Envisioning a future state in an ambiguous environment;

2. Enacting the vision by giving it direction and purpose and acquiring the necessary resources;

3. Enabling it to occur by harnessing the support by other people outside the organisation.

In addition, Defourny (2001; cited by Defourny and Nyssens, 2006: 6) suggest that the social dimensions of entrepreneurship can perhaps be encapsulated as follows: 
a. An explicit aim to benefit the community: One of the principal aims of social enterprises is to serve the community or a specific group of people. In the same perspective, a feature of social enterprises is their desire to promote a sense of social responsibility at local level;

b. An initiative launched by a group of citizens: Social enterprises are the result of collective dynamics involving people belonging to a community or a group that shares a well defined need or aim;

c. Decision-making power not based on capital ownership: This generally refers to the principle of "one member, one vote" or at least to a decision-making process in which the voting power in the governing body with the ultimate decision-making rights is not distributed according to capital shares;

d. A participatory nature, which involves the various parties affected by the activity: Representation and participation of users or customers, stakeholder influence on decision-making and participative management are often important characteristics of social enterprises;

e. Limited profit distribution: Social enterprises not only include organisations that are characterised by a total non-distribution constraint, but also organisations which may distribute profit, but only to a limited extent, thus avoiding profit-maximising behaviour.

However, measuring social entrepreneurship is a difficult task that cannot be resolved easily. This is due to the existence of a wide range of definitions about the object of investigation. Subsequently, not all social entrepreneurs will be working for revenues (either from grants or sales) and not all of these types of enterprises will become social. To this someone would add that much of the discussion about social entrepreneurship has at its core a frustration about its effectiveness. Awareness of this frustration, as a principle driver of change can be very limited (Harding and Cowing, 2004). The role of higher education institutions in enhancing social entrepreneurship can be seen in the next section in which a theoretical model of this role is described and the subsequent implications are presented.

\section{Higher education in enhancing social entrepreneurship}

\subsection{The trend for establishing (social) entrepreneurial education}

Higher education (HE) institutions worldwide, in particular the ones in the Western countries, have gone a long way regarding the type and quality of education they have been offering. To the author's knowledge and personal experience higher education has been required today to adapt as an objective to go beyond rote learning. This would lead to a process whereby knowledge and understanding are developed via the transformation of experience within a realistic environment. The fundamental assumptions of such education include a wide variety of activities consistent with the dynamic person-environment interaction. This is important in order to achieve understanding and a kind of 'hands-on' type of learning (Robinson and Malach, 2004). Crosby (1995; cited by Robinson and Malach, 2004: 319) suggests that based on those assumptions higher education becomes more reliable compared to traditional theories. She asserts that 'students educated according to these assumptions are better prepared to deal with the world than are students educated according to traditional epistemologies.' Having said this, study on $15 \mathrm{UK}$ universities that explored the reality of university-industry relationship concluded some not very positive outcomes. This was due to the culture shaping these universities that discouraged sharing of intra-organisational knowledge. This, as it was expected resulted to lack of flexibility and effective collaboration between universities and industry (Martin and Turner, 2010). However, the focus and emphasis of the university world often seems to contrast with the urgencies of the business 
and community-oriented audience. Practitioners are interested in output not process and in utility that could make them able to apply knowledge that could improve efficiency and profitability (Hindle et al, 2004). Someone would argue though that this communication gap between universities and practitioners could be transcended. A way of doing this might well be promotion of entrepreneurship within higher education. Knowledge offering based on reallife learning is not always viable and achievable, as it seems.

Nevertheless, entrepreneurial education has existed for a few years now and as Matlay (2006) points out this was initiated from research that was done on small businesses in the 1980s. Interestingly though, he continues there were very few designated research findings in this area most of them focussed upon finance, marketing, internationalisation and the technology aspects of small business development. This was because education, training, learning and human resources in smaller firms were not considered important enough to warrant much attention. Thankfully, things changed substantially in the early 1990s when new and established researchers began to take an interest in the "human aspect" of entrepreneurship and small business development. By the late 1990s, these topics had grown considerably in volume and quality of research. Moreover, the entrepreneurial mission has become increasingly apparent for quite a few universities in terms of teaching, research and services to society (Heinonen and Hytti, 2010; Martin and Turner, 2010).

\subsection{The (social) entrepreneurial orientation of Higher Education}

Therefore, social entrepreneurship should be considered as an emerging area in higher education learning. According to McElwee and Atherton (2005) there have not been significant contributions research-wise at least until a few years ago. It seems obvious that for such an underdeveloped subject area an educational approach is perhaps necessary in order to examine the role of higher education in enriching and enhancing social entrepreneurship, if this is the case. For the purpose of this paper a specific relevant theoretical approach has been used. It has been called in a series of cases the entrepreneurial orientation of an organisation and focuses on the organisational level of analysis (Todorovic, 2004). Theory although static it can be beneficial because it provides an informative theoretical framework for use, according to Fiet (2001 cited Todorovic, 2004). However, this is not always possible with entrepreneurship, (therefore social entrepreneurship) because they are closely linked with the "real-world" environment. Bjerke (2007) asks the question that many academics have faced with: Can entrepreneurship (and social entrepreneurship) be taught? Although not surprisingly most entrepreneurship scholars seem to advocate to a positive answer, the point is (according to Bjerke) to be able to clarify under what circumstances education takes place. In this light, issues that will have to be considered include:

- What are the educational objectives?

- Who are the students?

- To what extent should we ask the students to actually start a [social enterprise] venture during or after joining an educational programme?

- What are the teaching techniques and pedagogy used?

- What dimensions should be included when we assess the effect of the educational programme? (Bjerke, 2007: 225)

These are not easy questions to answer, especially with regard to such a novel subject area. Nevertheless, they seem useful to be presented in this context as a contribution to the constant debate about social entrepreneurship. Todorovic (2004) argues that entrepreneurship (thus its social element as well) is a field that needs the development of a dynamic component in addition to its theoretical basis. A dynamic component can be seen as an educational context 
that is affected by student activity and it is likely to grow in conjunction with the "real-world" environment. This component could be then presented in the classroom in a way that reflects the "real world". According to Heinonen and Hytti (2010) teaching about entrepreneurship involves that we encounter the subject as an academic field of study, therefore this implies that students should be equipped with relevant research skills and capabilities. In the past, this component was missing or it was not sufficiently developed regarding the education on entrepreneurship. Even the university culture of the time did not support the creation and development of such component. Figure 1 shows how this dynamic component can relate to social entrepreneurship education. This is presented in the context of an assumed entrepreneurial-orientation higher education institution and it is based on innovativeness, proactiveness and risk taking. This can be explained by the fact that a number of universities are making serious attempts to become more innovative, proactive and flexible nowadays (Menzies, 2002). A university that is innovative and proactive is better equipped to react to changes in a dynamic way rather than just accepting that changes happen (Todorovic, 2004). The significance of this framework is multifarious. Firstly, it increases the understanding of social entrepreneurship education. Secondly, it illustrates the importance of the university culture. Finally, by increasing the understanding of teaching social entrepreneurship it further contributes to university's future regarding better exploitation of opportunities. For example, the University of Waterloo in Ontario, Canada has launched the Centre of Business, Entrepreneurship and Technology programme (CBET). Recognising the impact of the university's entrepreneurial orientation the programme provides theory which is supplemented by activities that engage students in a venture related environment. This environment functions under the direction of social entrepreneurs (Todorovic, 2004). The example demonstrates a university social entrepreneurship programme that provides both dynamic and static elements to the training of future entrepreneurs.

[Please insert Figure 1 here]

Furthermore, in order to assess the position of social entrepreneurship and how higher education could contribute to its development, the subject area is examined according to the kind of environment it is implemented within. To this extent, two particular types of market environments are envisaged: social welfare markets on the one hand and "commercial" markets on the other. One would also consider a third kind of environment, the one of mixing characteristics and features of the first two types (Aiken, 2006). This orientation of social entrepreneurship is vital because it can determine the support higher education can offer as it can be seen with the cases of Bournemouth and Memorial Universities in the section with the empirical research findings. In a similar fashion, Dees et al (2001) describe the social entrepreneurship spectrum as a means of options social entrepreneurs have in order to structure their organisation. The social entrepreneurship spectrum is presented in Table 1 as an illustration of the two extremes of social enterprises - purely philanthropic organisations on one hand and purely commercial on the other - and all the other possibilities in between. It could then be argued that the social entrepreneurship spectrum complements the types of market environments social enterprises could develop.

[Please insert Table 1 here]

Finally, the degree of participation by the university students and members of staff in creating a climate of implementing successfully aspects of social enterprising is a determining factor that can heavily affect the scale of support higher education can offer in enhancing social entrepreneurship. All the aforementioned as well as the practical implications of social 
dimensions of entrepreneurship by Defourny, as they are described in the previous section of this paper are going to be tested and analysed in the context of Dorset, UK and Avalon, Canada through particular activities within the Bournemouth and Memorial universities respectively. Before this a brief account of methodological issues is being given.

\section{Methodological issues}

This research should be considered as an initial proactive reaction onto how social entrepreneurship could/should be part of the higher education life and get supported by it. In the light of this, it constitutes part of a research with a much broader scope that the author has planned to conduct especially with regard to the impact social entrepreneurship can have on local residents' life primarily in the area of Dorset, UK. This introductory character could perhaps be considered as its main limitation. Its qualitative character has been determined by the nature of the particular research to identify core aspects of university involvement with social entrepreneurship and how this can perhaps be feasible in a positive sort of a manner. Smith and Anderson (2007) point out that there is little qualitative research about entrepreneurship however the benefits of having it are worthy. They are self-evident but frequently only achieved as part of a broader research strategy.

Methodology-wise this paper is based upon primary research of qualitative nature via conduct of semi-structured interviews with university students and members of staff. The collection of primary data took place in both Bournemouth and Memorial Universities between September 2007 and March 2010. According to Yin (1994) interviewing is one of the most important sources of case study information. This was proved to be the case with this paper as the participant interviewees gave a comprehensive picture of where the two universities are heading with regard to the application of a social entrepreneurship framework and how they could perhaps contribute to it. To this extent, 12 interviews were conducted at both places. Additionally, it has also relied upon collection of secondary data. Especially in the case of Memorial University secondary data proved to be a very useful source of information, as it included a broad range of sources such as: interior case studies; local newspapers; and university archives.

\section{The cases of Bournemouth University, UK and Memorial University of Newfoundland, Canada - Discussion}

\subsection{Social Entrepreneurship at Bournemouth University}

Bournemouth University is one of the relatively new universities in the UK - since 1992. It has been pursuing entrepreneurship through governmental schemes e.g. Knowledge Transfer Partnerships (KTP) that in 2006 represented a portfolio of about $£ 1.7$ million of external funding (Bournemouth University, 2006b). It was pointed out that "the University's enterprise ambitions will be achieved through educational programmes, targeted Continuing Personal Development programmes, knowledge exploitation through licensing and spin-outs, knowledge transfer through consultancy, facilities provision, partnerships with external organisations and incentivising and rewarding staff' (Bournemouth University, 2006a: 7). Moreover, the university recognises that entrepreneurship should not be pursued only for financial gain and it is open to innovative ideas and collaborative forms that could include the Third sector and promote social entrepreneurship. However, a university review on entrepreneurship identified lack of information, advice and guidance with regard to its policies and how to go about getting enterprise work (Bournemouth University, 2008). Entrepreneurship and innovation are promoted via the university's Innovation Centre (BUIC) and the Centre for Research and Knowledge Transfer (CRKT). 


\subsection{Social Entrepreneurship at Memorial University of Newfoundland}

The PJ Gardiner Institute is the main promoter of entrepreneurship at the Memorial University of Newfoundland. The institute was established in 1978 and since then it "provides the necessary frameworks to develop and deliver outreach services to help make these ideas work. Its activities create a robust interaction with economic development agencies, and are an essential point of contact with the needs of real people in the real economy" (Memorial University of Newfoundland, 2008: front page). In September 2007 ACE Memorial, a student group created to promote entrepreneurship opened Launch Pad, Canada's first and only student business incubator operated by students. Launch Pad is a place where student entrepreneurs can operate and grow their business while attending classes (Gazette, September 20 ${ }^{\text {th }}, 2007$ ). Despite lack of official statement that supports social entrepreneurship by the university there have been indications of its development through the work of its members of staff and students. For example, Sheppard (2003: 124) pinpoints the significance of entrepreneurship with a social face, as 'the promotion and spread of entrepreneurial values have adopted the same processes used by social movements to advance their cause and get their message out everywhere.'

\subsection{Discussion}

The contribution by Bournemouth and Memorial Universities to social entrepreneurship can perhaps take the form of a comparison, as the two universities have differed in their selected approaches. Based upon primary and secondary data, the approach followed by Bournemouth University has come as a result of having a "philanthropic" attitude that is blended with the tendency to benefit from a commercial approach to social entrepreneurship. To this extent it could be argued that Bournemouth University has followed a hybrid approach to social entrepreneurship. Indicative to this is that the Enterprise Review of 2008 recommends firmly the university to 'develop a Strategy for the Region that identifies the key partners and stakeholders the University should work with' in order to gain social and economic benefits (Bournemouth University, 2008: 38).

In contrast, it could be argued that Memorial University has preferred a more commercial approach, which derived from its attitude towards entrepreneurship that is to see social entrepreneurship mainly as a way of profiting from it. This was clearly stated in the PJ Gardiner Institute' website, that it 'provides aspiring entrepreneurs with counselling advice and direction on a business idea to the point of business start-up' (Memorial University of Newfoundland, 2008). However, in the same website it is also stated that the Institute is 'open to all members of the university community including undergraduate and graduate students, faculty, staff, and alumni'. In addition it is open to the local community too, as one of its consultants pointed out:

'At the PJ Gardiner Institute whoever has walked through the door will be served.

We never say: no, you should go somewhere else. With that network we are entangled in, engaged so it's no problem for us to take them in to PJ Gardiner Institute and find what's best for them. So, you know it works well like that.' (From the interview with one of the business consultants at the Memorial University)

The choice of the manner each university deals with social entrepreneurship has reflected their motives, methods and goals as it can be seen in Table 2. This has obviously affected the way each university regards entrepreneurial activity. It could be argued that Bournemouth University has developed an entrepreneurial orientation culture in principle despite the fact that there are many more steps to be taken in order to achieve its social entrepreneurship 
goals. This culture and tendency to achieve more is explicitly mirrored in the Enterprise Review the university published in 2008 in which some of the recommended actions are: To re-brand its Centre for Research and Policy Transfer into Centre for Research and Enterprise which will have a more business-focused way of operating; to undertake robust economic assessment and competitor analysis of all university assets; to agree annual targets for commercialisation activity with the specific university schools; to enter into regional partnership schemes with existing enterprise hubs and groups (Bournemouth University, 2008). As someone would expect innovation, proactiveness and risk taking are still in the sphere of what could be desirable rather than happening.

\section{[Please insert Table 2 here]}

This is not the case with Memorial University though because it has already reached a well defined state of entrepreneurial orientation culture. This is reflected in the university's curriculum. For example, the Faculty of Business created the position of the Chair in YouthFocused Technological Entrepreneurship, which encompasses responsibilities of conducting relevant research, creating new ventures; and support entrepreneurship within the subject areas of business, engineering, science and medicine. In addition, the PJ Gardiner Institute introduced a series of initiatives such as: the Entrepreneur-in-Residence initiative; scholarships and awards to recognise entrepreneurial endeavours, business plans, etc; the ACE Memorial support, a national award winning faculty advisor; and the Dobson Foundation support (Power, 2007). In this respect, it would be fair to claim that Memorial University has had well established innovation, proactiveness and risk taking approaches.

With regard to how far the two universities have gone with the promotion of an attitude towards social entrepreneurship it is interesting to notice that their social entrepreneurship attributes play a major part in their choices. In this light, Bournemouth University accepts the fact that it follows a hybrid option by having both "social" and "commercial" interests. This was explicit by the representative of the student entrepreneurship group who noted that:

'I think we make an impact to local community...[but] I can't really say what impact we have made as a society because we started six months ago...It's an ongoing process really so hopefully this time next year we have a much more greater contribution to local community... I would like to think that we educate the local community but again what we like to change is to work with organisations such as Business Link...I think if we establish a relationship with Business Link and then it will all follow from there with the resources we would have here they [businesses] could be promoted through to people they know and that can get local community involved.'

(From the interview with the representative of the student entrepreneurship group at Bournemouth University)

As for Memorial University there is no evidence at all that they have developed initiatives that would benefit the community. As a result, any decisions on entrepreneurship members of staff and students have made were based on the principle to own and increase capital wherever possible. In addition, there is no such thing as "limited profit distribution", quite the opposite. The latter applies to the case of Bournemouth as well. Having said that, there is evidence of willingness to see entrepreneurship as affecting the local community in a positive way in the long run, as one of the young entrepreneurs at the Launch Pad event suggested:

'So I think that just economic factors have forced people to be innovative to be entrepreneurial to create opportunities for themselves here. Projects like Launch Pad allows 
the next generation, our generation to have another alternative in building a future here instead of going to the mainland or another place. Anytime you can keep somebody here, a young person that is going to build a business here and employ other people then you build a boost for everyone.'

(Young entrepreneur at Memorial University)

Ultimately, with respect to the degree of participation by university members of staff and students from the conducted interviews it became apparent that there are an increasing number of people in both universities who support the development of an entrepreneurship tradition via attendance of relevant events, provision of relevant material and giving talks in relevant events, etc. Taking this discussion into account it can perhaps be argued that the establishment of social entrepreneurship orientation is a step that cannot come easily. It is this that should change first in order for the university attitude towards social entrepreneurship to change.

\section{Conclusion}

Considering all the aforementioned viewpoints, it can perhaps be argued that the establishment of a social entrepreneurship orientation in an organisation is a vital step towards economic and social growth although it cannot be achieved easily. It is this step that should be obtained first in order for an organisation's (a university's in the case of this paper) attitude towards social entrepreneurship to change. Higher education can be supportive in enhancing social entrepreneurship in policy terms as long as entrepreneurial orientation and attitude towards social entrepreneurship are developed within it. This is an issue that should be under governmental scrutiny, especially now that social entrepreneurship's development has begun to get increasingly significant momentum. From the research findings it can be argued that despite the fact that they see things through different spectacles, Bournemouth University and Memorial University of Newfoundland are in the position to smile regarding enhancement of social entrepreneurship for three reasons: they have established a basis for entrepreneurial orientation; they have created a culture towards development of entrepreneurship; and they are concerned about the social effect entrepreneurship might have to the life of their respective community.

However, there are a number of hurdles that have to be overcome such as: further focus on how entrepreneurship can benefit their community; further enhancement of limited profit distribution; creating a decision-making system that would not be dependent exclusively on capital ownership; and increasing further an atmosphere of collaboration and synergy. It is at the end of the day these findings that could advance planning of research on social entrepreneurship in the future by investigating case studies outside the university web and within the local society. More than all these it has to be said that the influence of social entrepreneurship to university life is still in its infancy hence some substantial steps should be expected for the future. As Light (2008) argues the core question is not how much socially entrepreneurial activity exists, but how it can be explored to its maximum. And this obviously must involve carefully designed research.

\section{References}

Aiken, M (2006) "Towards market or state? Tensions and opportunities in the evolutionary path of three UK social enterprises" in Nyssens, M. (ed.) Social Enterprise - At the crossroads of market, public policies and civil society, Routledge, London, pp. 259-271 
Bjerke, B (2007) Understanding Entrepreneurship, Edward Elgar Publishing Ltd, Cheltenham

Bournemouth University (2006a) Corporate Plan - A statement of strategic intent Poole: Bournemouth University

Bournemouth University (2006b) Review Poole: Bournemouth University

Bournemouth University (2008) Enterprise Review - Recommendations for improving the quality of Enterprise and Research support at Bournemouth University Poole: Bournemouth University

Defourny, J. \& Nyssens, M. (2006) "Defining Social Enterprise" in Nyssens, M. (ed.) Social Enterprise - At the crossroads of market, public policies and civil society, Routledge, London, pp. 3-26

Dees, J.G., Emerson, J. \& Economy, P. (2001) Enterprising Nonprofits: A toolkit for Social Entrepreneurs, J. Wiley \& Sons, Inc, Toronto

Drayton, W. (2006) "Everyone a Changemaker - Social Entrepreneurship's Ultimate Goal" Innovations, Winter, pp. 80-96

Ebner, A (2003) "The Institutional Analysis of Entrepreneurship: Historist Aspects of Schumpeter's Development Theory" in JG Backhaus, ed, Joseph Alois Schumpeter: Entrepreneurship, Style and Vision Kluwer Academic Publishers, Dordrecht [e-book]

Gazette (2007) Wanted: student entrepreneurs to be launched to success (the newspaper is a Memorial University of Newfoundland publication), $20^{\text {th }}$ September, $5 \mathrm{a}$

Heinonen, J \& Hytti, U (2010) "Back to basics: the role of teaching in developing the entrepreneurial university" The International Journal of Entrepreneurship and Innovation, Vol. 11, No.4, pp. 283-292

Harding, R. \& Cowing, M. (2004) Social Entrepreneurship Monitor United Kingdom 2004, London Business School, London

Hindle, K., Anderson, R.B. \& Gibson, B. (2004) "From What We Know to How We Use It: Five Principles for Turning Entrepreneurship Research into Practitioner Action Guidelines" Journal of Small Business \& Entrepreneurship, Vol. 17, No. 4, Fall, pp. 261-266

Kuratko, DF \& Hodgetts, RM (2007, $7^{\text {th }}$ Edition) Entrepreneurship - theory, process, practice Thomson South-Western, Canada

Light, PC (2008) The search for social entrepreneurship The Brookings Institution, Washington DC [e-book]

Martin, L \& Turner, P (2010) "Entrepreneurial universities: the key ingredient in the recipe for UK innovation? Realities of working in business engagement roles in academia" The International Journal of Entrepreneurship and Innovation, Vol. 11, No.4, pp. 273-281 
Matlay, H (2006) "Entrepreneurship education: more questions than answers?" Education and Training Vol. 48, No. 5, pp.289-295

McElwee, G \& Atherton, A (2005) "Publication trends and patterns in entrepreneurship - The case of The International Journal of Entrepreneurship and Innovation" Journal of Small Business and Enterprise Development Vol. 12 No. 1, pp. 92-103

Memorial University of Newfoundland (2008) PJ Gardiner Institute for Enterprise and Enterpreneurship - Innovate, Collaborate, Educate [Available from the Internet - accessed on $28^{\text {th }}$ April 2008] <URL: http://www.business.mun.ca/pjg/>

Menzies, T. ed. (2002) Entrepreneurship and the Canadian Universities - Strategies and Best Practices of Entrepreneurship Centres, Brock University, St. Catharines - Ontario

Okpara, J.O. \& Halkias, D. (2011) "Social Entrepreneurship: an overview of its theoretical evolution and proposed research model" International Journal of Social Entrepreneurship and Innovation, Vol. 1, No. 1. pp. 4-20

Power, R (2007) Lighting fires: Entrepreneurship Support in the Faculty of Business (Presentation at the CABI Conference on $24^{\text {th }}$ Sept. 2007)

Robinson, P. \& Malach, S. (2004) "Multi-disciplinary Entrepreneurship Clinic: Experiential Education in Theory and Practice" Journal of Small Business \& Entrepreneurship, Vol. 17, No. 4, Fall, pp. 317-332

Sandler, MR (2010) Social entrepreneurship in education - private ventures for the public good Plymouth: Rowman \& Littlefield Education

Sheppard, T. (2003) Means of survival: Youth unemployment and entrepreneurial training in Newfoundland (Unpublished Masters dissertation, Dept of Sociology, MUN) Memorial University of Newfoundland

Smith, R \& Anderson, AR (2007) "Daring to be different: a dialogue on the problems of getting qualitative research published" in H. Neergaard \& JP Ulhoi Handbook of Qualitative Research Methods in Entrepreneurship Edward Elgar Publishing Ltd, Cheltenham

Social Enterprise Coalition (2003) There's more to business than you think, Social Enterprise Coalition, London

The Observer (2005) Social Enterprise $20^{\text {th }}$ November, 1a

The Trees Group (2008) The Story so far [accessed from the Internet on 13 April 2008] <URL: http://www.thetreesgroup.org.uk/about.html>

Thompson, J., Alvy, G. \& Lees, A. (2000) "Social entrepreneurship - a new look at the people and the potential" Management Decision, Vol. 38, No 5, pp. 328-338

Todorovic, Z.W. (2004) "The Framework of Static and Dynamic Components: An Examination of Entrepreneurial Orientation and University Ability to Teach 
Entrepreneurship" Journal of Small Business \& Entrepreneurship, Vol. 17, No. 4, Fall, pp. 300-316

Yin, R. (1994, $2^{\text {nd }}$ edition) Case study research - Design and methods, SAGE Publications, Thousand Oaks

\section{Bibliography}

Corporate Research Associates Inc (2001) Study of Entrepreneurship among Young Atlantic Canadians 15-29 Halifax: Corporate Research Associates

Gartner, WB \& Shane, SA (1995) "Measuring Entrepreneurship over Time" Journal of Business Venturing, Vol. 10, No. 4, pp. 283-302

Goss, D (2008) "Enterprise Ritual: A Theory of Entrepreneurial Emotion and Exchange" British Journal of Management, Vol. 19, No.2, pp. 120-137

Legge, J. \& Hindle, K. (2004, $2^{\text {nd }}$ Edition) Entrepreneurship - Context, vision and planning, Palgrave Macmillan, Basingstoke

McLeod, H. (1997) “The New Social Entrepreneurs” Who Cares, p.34

Shane, S \& Venkataraman, S. (2000) "The Promise of Entrepreneurship as a Field of Research", Academy of Management Review, Vol.25, pp. 217-26

Studdard, N.L. \& Darby, R. (2011) "Social Entrepreneurship: managing strategic decisions in Social Entrepreneurial organisations" International Journal of Social Entrepreneurship and Innovation, Vol. 1, No. 1. pp. 66-78

The Observer (2007) Enterprising Solutions $21^{\text {st }}$ October, 1a

Wickham, P.A. (1998) Strategic Entrepreneurship, Pitman Publishing, London 
Institutional Culture

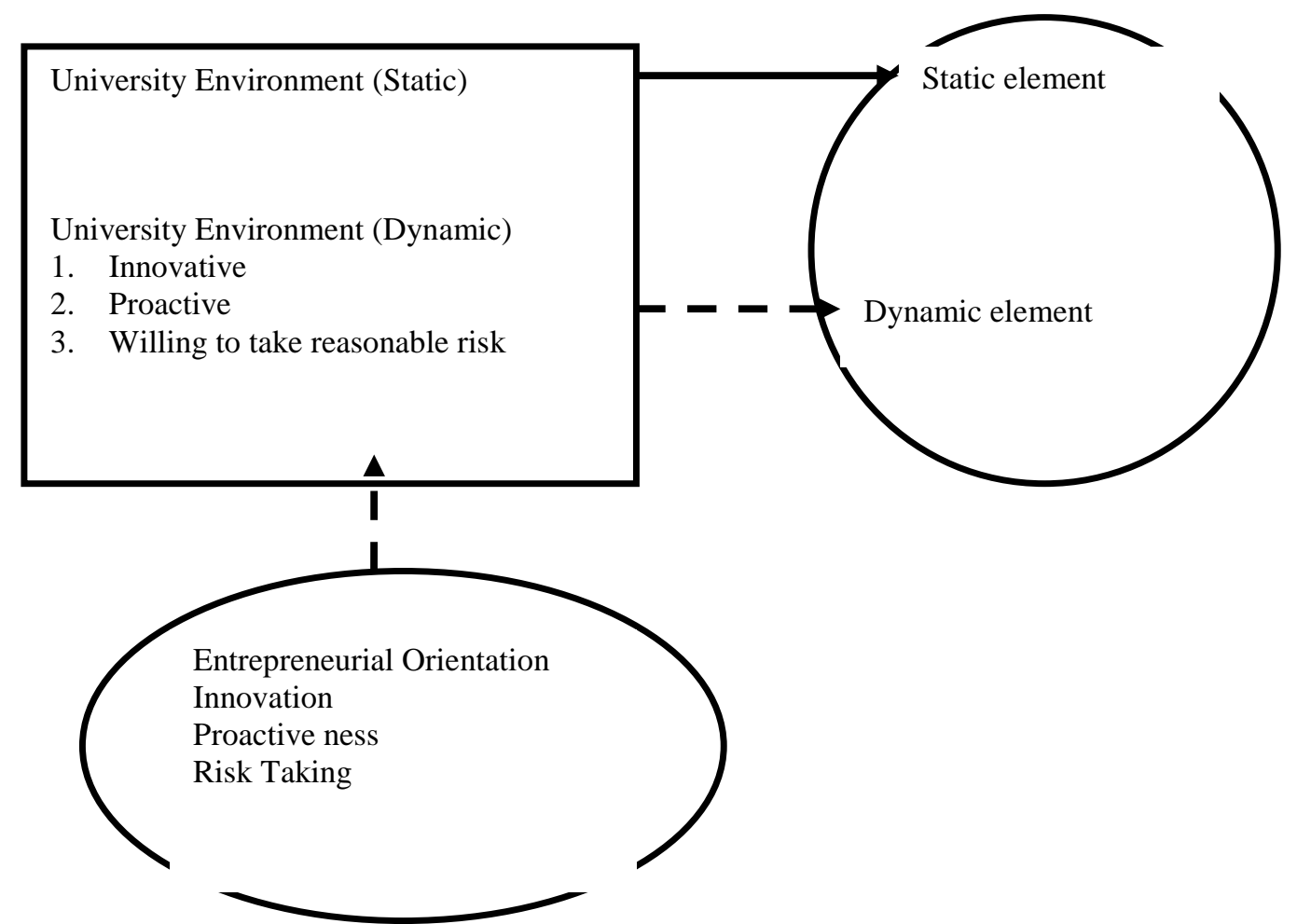

Social Entrepreneurship

Education Activity

Static elemen

Figure 1: Conceptual framework of Social Entrepreneurship Education at an Entrepreneurially Oriented University (Adapted from Todorovic, 2004: 307) 


\begin{tabular}{|l|l|l|l|}
\hline \multicolumn{1}{|c|}{} & \multicolumn{1}{|c|}{$\begin{array}{c}\text { Continuum of Options } \\
\text { philanthropic }\end{array}$} & \multicolumn{1}{|c|}{ Hybrids } & Purely Commercial \\
\hline General Motives & Appeal to goodwill & Mixed motives & $\begin{array}{l}\text { Appeal to self- } \\
\text { interest }\end{array}$ \\
\hline Methods & Mission-driven & $\begin{array}{l}\text { Balance of mission } \\
\text { and market }\end{array}$ & Market-driven \\
\hline Goals & Social value creation & $\begin{array}{l}\text { Social and economic } \\
\text { value }\end{array}$ & $\begin{array}{l}\text { Economic value } \\
\text { creation }\end{array}$ \\
\hline
\end{tabular}

Table 1: The social entrepreneurship spectrum (Adopted from Dees et al, 2001: 15) 


\begin{tabular}{|c|c|c|}
\hline & Bournemouth University & $\begin{array}{c}\text { Memorial University of } \\
\text { Newfoundland }\end{array}$ \\
\hline \multicolumn{3}{|l|}{$\begin{array}{l}\text { UNIVERSITY } \\
\text { ATTRIBUTES }\end{array}$} \\
\hline Motives & Mixed motives & Appeal to self-interest \\
\hline Methods & $\begin{array}{l}\text { Balance of mission and } \\
\text { market }\end{array}$ & Market-driven \\
\hline Goals & Social and economic value & Economic value creation \\
\hline University environment & More static than dynamic & Dynamic \\
\hline $\begin{array}{l}\text { Entrepreneurial } \\
\text { orientation }\end{array}$ & $\begin{array}{l}\text { Principally yes but at an } \\
\text { early stage }\end{array}$ & Yes \\
\hline Innovation & $\begin{array}{l}\text { Principally yes but at an } \\
\text { early stage }\end{array}$ & Yes, well established \\
\hline Proactiveness & $\begin{array}{l}\text { Principally yes but at an } \\
\text { early stage }\end{array}$ & Yes, well established \\
\hline Risk Taking & $\begin{array}{l}\text { Principally yes but at an } \\
\text { early stage }\end{array}$ & Yes, well established \\
\hline \multicolumn{3}{|l|}{$\begin{array}{l}\text { UNIVERSITY } \\
\text { ATTITUDE TOWARDS } \\
\text { SOCIAL } \\
\text { ENTREPRENEURSHIP }\end{array}$} \\
\hline $\begin{array}{l}\text { An explicit aim to benefit } \\
\text { the community }\end{array}$ & In principle, yes & $\begin{array}{l}\text { No, but there is evidence } \\
\text { for willingness to change in } \\
\text { the future }\end{array}$ \\
\hline $\begin{array}{l}\text { An initiative launched by } \\
\text { a group of citizens }\end{array}$ & $\mathrm{N} / \mathrm{a}$ & $\mathrm{N} / \mathrm{a}$ \\
\hline $\begin{array}{l}\text { Decision-making power } \\
\text { not based on capital } \\
\text { ownership }\end{array}$ & The opposite applies & The opposite applies \\
\hline $\begin{array}{l}\text { A participatory nature, } \\
\text { which involves the } \\
\text { various parties affected } \\
\text { by the activity }\end{array}$ & In principle, yes & $\begin{array}{l}\text { No, but there is evidence } \\
\text { for willingness to change in } \\
\text { the future }\end{array}$ \\
\hline $\begin{array}{ll}\text { Limited } & \text { profit } \\
\text { distribution } & \end{array}$ & The opposite applies & The opposite applies \\
\hline
\end{tabular}

Table 2: The social entrepreneurship spectrum at Bournemouth University and Memorial University of Newfoundland 